\section{Actinidia Germplasm Resources and Kiwifruit Industry In China}

\author{
Hongwen Huang, ${ }^{1}$ Ying Wang, ${ }^{2}$ Zhonghui Zhang, Zhengwang Jiang, \\ and Shengmei Wang \\ Wuhan Botanical Garden-Wuhan Institute of Botany, The Chinese Academy \\ of Sciences, Wuhan, Hubei 430074, P.R. China
}

Kiwifruit is native to China, and today's cultivated kiwifruit are the large-fruited and good-flavored selections of two commercially developed Actinidia species: A. deliciosa C.F. Liang et A.R. Ferguson and A. chinensis Planch. The genus Actinidia Lindl. comprises 66 species and about 118 taxa, with a remarkably wide natural range extending from the tropics (latitude $0^{\circ}$ ) to cold temperate regions $\left(50^{\circ} \mathrm{N}\right)$. With the exception of four species native to neighboring countries (A. strigosa Hook \& Thoms. in Nepal, A. petelotii Diels in Vietnam, A. hypoleuca Nakai and A. rufa (Sieb. et Zucc.) Planch ex Miq. in Japan), all other 62 species, about 45 varieties, and 7 forms occur naturally in China (Cui, 1993; Ferguson, 1990; Huang et al., 2000; Liang, 1983). Such an unusually wide range of variation of species diversity and rich genetic resources provides tremendous potential for cultivar improvement and sustainability enhancement of the world kiwifruit industry. It is impossible therefore to ignore the value of Actinidia genetic resources in China, which occurs both naturally in the wild and is conserved in field repositories (Huang, 2003).

The economic potential of $A$. deliciosa was exploited following the first seed introduction from China in 1904 and the first commercial vineyard appeared in New Zealand in 1930 (Ferguson and Bollard, 1990). Since the 1970s, an international kiwifruit industry of $>100,000$ ha has been developed with annual production of $1 \times 10^{6} \mathrm{t}$ (Huang and Ferguson, 2001). The successful development of kiwifruit industries, first in New Zealand and then in other countries, has stimulated China's interest in the potential of native Actinidia species, although China has a long history of local consumption of the Actinidia as fresh fruit, functional foods, Chinese herbal medicines, and as much as $150,000 \mathrm{t}$ fresh fruit per year were collected from the wild (Cui, 1993). This wild harvesting has occurred for centuries, but until about 20 years ago, only very few sporadic attempts at cultivation have been made (Ferguson, 2001).

\footnotetext{
Received for publication 29 Apr. 2003. Accepted for publication 22 Aug. 2003. This research was partially supported by NSF of China (30070082), the CAS-project KSCX2-SW-104, and the European Union (INCO-DC IC18CT970183).

${ }^{1}$ To whom reprint request should be addressed. Professor of Plant Genetics and Breeding, Wuhan Institute of Botany, The Chinese Academy of Sciences, Wuhan, Hubei 430074, P.R. China; e-mail hongwen@public.wh.hb.cn.

${ }^{2}$ Current address: Department of Plant Breeding, Cornell University, Ithaca, NY 14853.
}

A nationwide selection program was initiated by the Chinese government in 1977-78. The program resulted in $>1400$ superior genotypes being selected from wild populations of $A$. chinensis, A. deliciosa, and A. arguta (Sieb. et Zucc.) Planch et Miq. Most of these selections were topworked at research stations and evaluated. Subsequently, experimental trials, regional tests, and replicated trials of commercial scale resulted in 57 cultivars and a large number of selections (Cui, 1993). The outcome of this program made a unique situation for the Chinese kiwifruit industry with a different cultivar structure from the rest of the world. Since 1978 when commercial kiwifruit vineyards were first established in Hubei and Sichuan provinces using 'Hayward' (developed in New Zealand), commercial plantings have continuously increased to the present 57,396 ha. China now has $>40 \%$ of all the planted kiwifruit in the world. Production likewise increased rapidly from 5,000 t in 1990 to $291,450 \mathrm{t}$ in 2001. It is estimated that in 2002, the total production of kiwifruit in China was about 340,420 t. China has now surpassed New Zealand and Italy and has become the largest kiwifruit producer in the world (Huang and Ferguson, 2001). The current rapid growth of the world kiwifruit industry and its future sustainability will depend to a large extent on a thorough and continuous exploitation of the rich genetic resources and a sound management and conservation strategy for the germplasm. Since the late 1970s, extensive research has been conducted exploring genetic resources in China and has generated a wealth of information on the extent of genetic variation that exists. Our enhanced understanding of many basic aspects for further germplasm exploitation will lead us toward the development of a sustainable kiwifruit industry in China. Unfortunately, little of this basic information has been published in western languages. In this paper, we provide an overall review of the basic information that has been gathered on Actinidia germplasm and the development of Chinese kiwifruit industry over the past 2 decades.

\section{GENETIC DIVERSITY AND GERMPLASM RESOURECES OF GENUS ACTINIDIA}

\section{Morphological Variation for}

\section{Horticulturally Important Traits}

Tremendous phenotypic variations at both the interspecific and intraspecific level were observed in fruit traits (Table 1). For fruit weight, the interspecific variation ranges from
$0.6 \mathrm{~g}$ in A. maloides Li to $240 \mathrm{~g}$ in A. deliciosa. The two most commercially important species, $A$. deliciosa and $A$. chinensis, have the largest fruit, but significant variation in fruit weight is also observed within both species. A. chinensis fruit weight ranges from 20 to $120 \mathrm{~g}$, while that of A. deliciosa ranges from 30 to $200 \mathrm{~g}$. In general, all fruit are oval and spherical in shape. There are at least 15 different fruit shapes that have been identified: ovate-globose, flat globose, oblong, near globose, ellipsoid, short cylindric, cylindric, ovoid, long globose, ovatecylindric, long cylindric, ovoid-cylindric, long cone, ovate-cone, and ovoid-globose. One of the main breeding goals has been to develop cultivars with lighter skin than 'Hayward'. Although intraspecific variation of skin color is very limited and hardly genetically manageable, interspecific variation is broad and genetically heritable in most species. The interspecific variation of the fruit skin color ranges from brown to green, yellow, orange, light red, and even purple (Table 1).

Most Actinidia species have fruit skin covered with unpleasant pubescence. The stiff and long hairs of 'Hayward', selected from A. deliciosa, are considered undesirable and should be improved by future breeding and selection. A wide range of interspecific variation in type and amount of pubescence exists within the genus. This variation provides the breeding potential to improve this trait, and even a smooth skinned apple-like fruit may be developed in the future. There exits a continuous variation in skin pubescence ranging from long, stiff hairs on A. setosa (Li) C.F. Liang et A.R. Ferguson to the smooth skinned applelike fruit of A. arguta. Actinidia arguta has a nice glabrous skin, but is small in size. This species has been successfully used in interspecific breeding for creating large sized, smooth skinned fruit. Actinidia macrosperma C.F. Liang has smooth orange-colored skin when ripe, making it a suitable parent for breeding efforts. It has also been used to improve skin color and heat tolerance. Actinidia has a wide range of flesh color although commercial cultivars are either green or yellow-fleshed. Flesh color varies from light green to orange, dark red or purple. Flesh color has been considered a trait with strong gene $\times$ environment interactions. In most warmer climate regions, red flesh color (usually red color around fruit core ring) in some selections of both A. deliciosa and A. chinensis can be discovered in late spring to early summer, however, the red color becomes faded in midsummer. At high elevations where large day-night temperature fluctuations exist, red color can persist until maturity (Huang, personal observation). Most species produce edible fruit, but fruit taste varies considerably. The species with excellent palatable fruit are A. chinensis, A. arguta, A. kolomikta (Maxim. et Rupr.) Maxim., A. callosa Lindl., $A$. chrysantha Liang, and $A$. hubeiensis Sun et Huang. A. polygama (Sieb. et Zucc.) Maxim. is the least palatable with a mix of bitterness, astringency and a shocking mouth numbing effect. More detailed morphological variation of horticulturally important fruit characteristics are listed in Table 1. 
Table1. Diversity of fruit characters in genus Actinidia ${ }^{\mathrm{Z}}$.

\begin{tabular}{|c|c|c|c|c|}
\hline Species & $\begin{array}{l}\text { Fruit } \\
\text { shape }\end{array}$ & $\begin{array}{l}\text { Fruit } \\
\text { wt (g) }\end{array}$ & $\begin{array}{l}\text { Skin } \\
\text { color }\end{array}$ & $\begin{array}{l}\text { Skin } \\
\text { hairs }\end{array}$ \\
\hline A. arguta & $\begin{array}{l}\text { Ovate-globose, flat globose oblong, } \\
\text { near globose }\end{array}$ & $4-20$ & Light red, purple & Glabrous and smooth \\
\hline A. arisanensis & Near globose, ellipsoid & $5-10$ & Brown & Coarse hairs but shed \\
\hline A. callosa & Near globose, short cylindric & $8-9$ & Green & Glabrous \\
\hline A. chengkouensis & Near globose, cylindric & $10-35$ & Brown & Brown tomentose \\
\hline A. chinensis & Ellipsoid & $20-120$ & Brown & Brown short-tomentose but readily shed \\
\hline A. chrysantha & $\begin{array}{l}\text { Short cylindric, ovoid } \\
\text { long globose }\end{array}$ & $10-30$ & $\begin{array}{l}\text { Chestnut brown, } \\
\text { brown-green }\end{array}$ & Glabrous \\
\hline A. cinerascens & Ovate-cylindric & $5-10$ & & \\
\hline A. cylindrica & Long cylindric & $0.5-1$ & Dark green & Glabrous \\
\hline A. deliciosa & Long cylindric & $30-200$ & Brown-green & Dense with yellow-brown coarse hairs \\
\hline A. eriantha & Long cylindric & $10-40$ & Green & Dense with white villose \\
\hline A. farinose & Ovoid-cylindric & $1-2$ & Light green & Short-tomentose but readily shed \\
\hline A. fasciculoides & Long cylindric & & Dark green & \\
\hline A. fortunatii & Long cylindric & $1-2$ & Dark green & Yellow short-tomentose \\
\hline A. fulvicoma & Near cylindric & $3-4$ & Dark green & Yellow long-tomentose \\
\hline A. glauco-callosa & Flat globose & $10-15$ & Green, red-brown & Glabrous \\
\hline A. glaucophylla & Slender cylindric & $1-5$ & Brown & \\
\hline A. globosa & Near globose & $10-25$ & Brown & Glabrous \\
\hline A. gracilis & Ovoid, cylindric & $5-10$ & Brown & Glabrous \\
\hline A. grandiflora & Cylindric, ellipsoid & $20-60$ & Brown & Grayish white or yellow-brown downy hairs \\
\hline A. guilinensis & Globose & $10-25$ & Green & Glabrous but spotted distinctly \\
\hline A. hemsleyana & Cylindric & $16-30$ & Brown & Densely grayish yellowish brown setose \\
\hline A. henanensis & Cylindric & $15-23$ & Red & Glabrous and smooth \\
\hline A. henryi & Near cylindric, long cone & $2-8$ & Green & Glabrous but spotted distinctly \\
\hline A. hubeiensis & Ovate-cone & $5-9$ & Dark green & Glabrous but spotted distinctly \\
\hline A. indochinensis & Short ellipsoid & $6-8$ & Brown & Glabrous but spotted distinctly \\
\hline A. jiangxiensis & Ovoid-globose & $15-25$ & Yellow-green & Brown downy hairs only at apex \\
\hline A. kolomikta & Long-cylindric or long-globose & $2-10$ & Green and yellow-green & Glabrous and smooth \\
\hline A. lanceolata & Long cylindric, globose ovoid & 1 & Light brown & Glabrous \\
\hline A. latifolia & Cylindric & $2-4$ & Brown-green & Glabrous but spotted distinctly \\
\hline A. leptophylla & Short cylindric, short ellipsoid & $1-5$ & Green & Brown short-tomentose \\
\hline A. liangguangensis & Long cylindric & $1-4$ & Green & Coarse short-tomentose \\
\hline A. lijiangensis & Cylindric & $20-35$ & Green & Densely brown spotted \\
\hline A. macrosperma & Ovoid, ovoid-globose & $15-25$ & Orange & Glabrous and smooth \\
\hline A. maloides & Globose & $0.5-0.7$ & Yellowish brown and green & Glabrous \\
\hline A. melanandra & Near cylindric & $10-20$ & Brown & Glabrous \\
\hline A. melliana & Cylindric & $1-4$ & Light green & Short and sparsely coarse hairs \\
\hline A. obovata & Cylindric & $8-23$ & Brown green & Densely with brown tomentose \\
\hline A. persicina & Short cylindric & $13-18$ & Brown green & Densely with brown tomentose \\
\hline A. pilosula & Globose & & Green & Glabrous \\
\hline A. polygama & $\begin{array}{l}\text { Near long flat-cylindric or } \\
\text { flat cone }\end{array}$ & $5-9$ & Green and yellow-green & Glabrous and smooth \\
\hline A. rubricaulis & Long cylindric & $0.8-1$ & Dark green & \\
\hline A. rubus & Near globose & 4-9 & Green & Glabrous \\
\hline A. rudis & Long cylindric & 1 & Green & Glabrous \\
\hline A. rufotricha & Ovoid, cylindric & $10-19$ & & \\
\hline A. sabiaefolia & Ovoid & $12-25$ & Dark green & Glabrous \\
\hline A. setosa & Near globose, ovoid & $20-35$ & Brown & Densely with brown long strigose \\
\hline A. sorbifolia & Long cylindric & $9-15$ & Green & Densely with brown tomentose and fruit spots distinctly \\
\hline A. styraciflia & Cylindric & $2-4$ & Green & With green fruit spots \\
\hline A. suberifolia & Near globose & $10-20$ & Brown & Tea-brown tomentose \\
\hline A. tetramera & Ovoid, ellipsoid & $0.8-3.0$ & Brown & Glabrous \\
\hline A. trichogyna & Near globose, ovoid, long cylindric & $12-20$ & Dark green & Glabrous but spotted distinctly \\
\hline A. truneatifolia & Ovoid, wide ovoid & $4-8$ & Dark yellow & Sparsely tomentose or spotted \\
\hline A. umbelloides & Ovoid, short ellipsoid & $10-20$ & Green & Sparsely white tomentose \\
\hline A. valvata & Ovoid & $7-12$ & Orange & Glabrous and smooth \\
\hline A. venosa & Near ovoid or short cylindric & $2-8$ & Green & Sparsely light brown tomentose \\
\hline A. vitifolia & Short cylindric & $21-35$ & Brown & Brown tomentose \\
\hline A. zhejiangensis & Near globose & $15-25$ & Green-yellow & Silver white long tomentose \\
\hline
\end{tabular}

${ }^{2}$ Data source: 1980-85 provincial reports of Actinidia germplasm survey; Cui, Z. (eds.), 1993. Actinidia in China. Shandong Science and Technology Press;

Database of Actinidia research center, Wuhan Institute of Botany, CAS. 


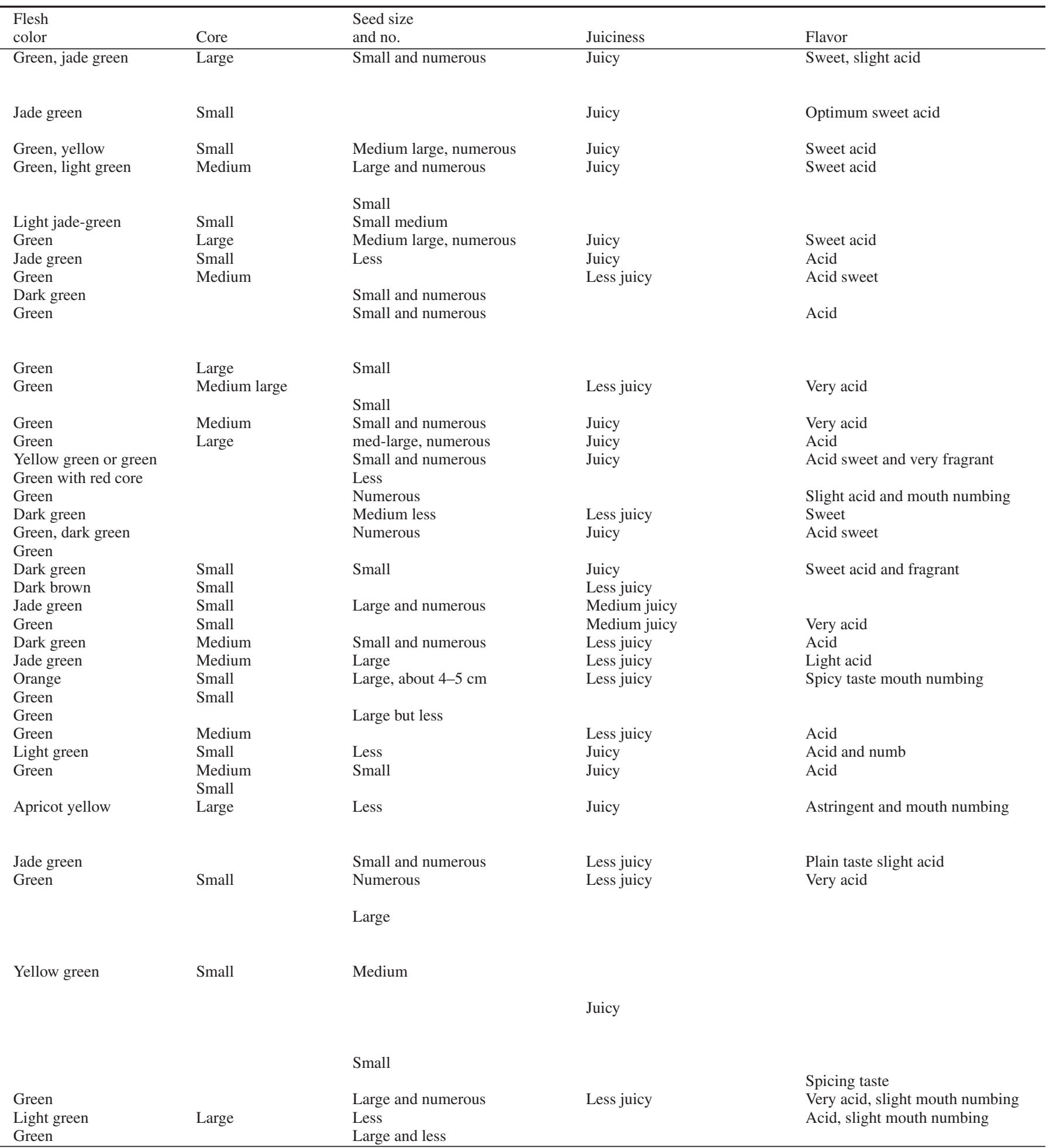


Variation of Nutritional and Chemical Constituents

When kiwifruit was in the early stages of commercialization, its nutritional value played an important role for commercial promotion in the fresh fruit market. The fruit has a high content of vitamin $\mathrm{C}$, minerals and dietary fiber. The vitamin $\mathrm{C}$ content in commercially produced kiwifruit can be as high as $>80 \mathrm{mg} / 100 \mathrm{~g}$ fresh fruit, about 2 to 3 times higher than oranges and 5 to10 times higher than apples. The kiwifruit was once called the king of fruit in China because of its high vitamin $\mathrm{C}$ content. A wide range of vitamin $\mathrm{C}$ was observed among species ranging from $5 \mathrm{mg} / 100 \mathrm{~g}$ in A. rudis Dunn to $2140 \mathrm{mg} / 100$ $\mathrm{g}$ in A. latifolia (Gardn. et Champ.) Merr. The species with high vitamin $C$ content include $A$. latifolia (671 to $2140 \mathrm{mg} / 100 \mathrm{~g}$ ), A. eriantha Benth.(500 to $1379 \mathrm{mg} / 100 \mathrm{~g})$, A. styraciflia C.F. Liang $(642 \mathrm{mg} / 100 \mathrm{~g})$, A. zhejiangensis C.F. Liang (289 to $371 \mathrm{mg} / 100 \mathrm{~g}$ ), A. persicina
Huang et Wang ( $314 \mathrm{mg} / 100 \mathrm{~g})$, A. cinerascens C.F. Liang (50 to $420 \mathrm{mg} / 100 \mathrm{~g}$ ), A. chinensis (50 to $420 \mathrm{mg} / 100 \mathrm{~g}$ ), and $A$. grandiflora C.F. Liang ( 56 to $214 \mathrm{mg} / 100 \mathrm{~g}$ ). The most widely grown A. deliciosa cultivar-'Hayward'-has the following composition: vitamin $\mathrm{C} 50$ to $150 \mathrm{mg} / 100 \mathrm{~g}$, soluble solids $12 \%$ to $18 \%$, total sugar $7 \%$ to $13 \%$, titratable acidity $1.1 \%$ to $1.6 \%$, protein $0.11 \%$ to $1.2 \%$, major minerals of calcium, magnesium and phosphorous ranging from $0.01 \%$ to $0.03 \%$, high potas-

Table 2. Variation of main nutritional constituents in genus Actinidia ${ }^{2}$.

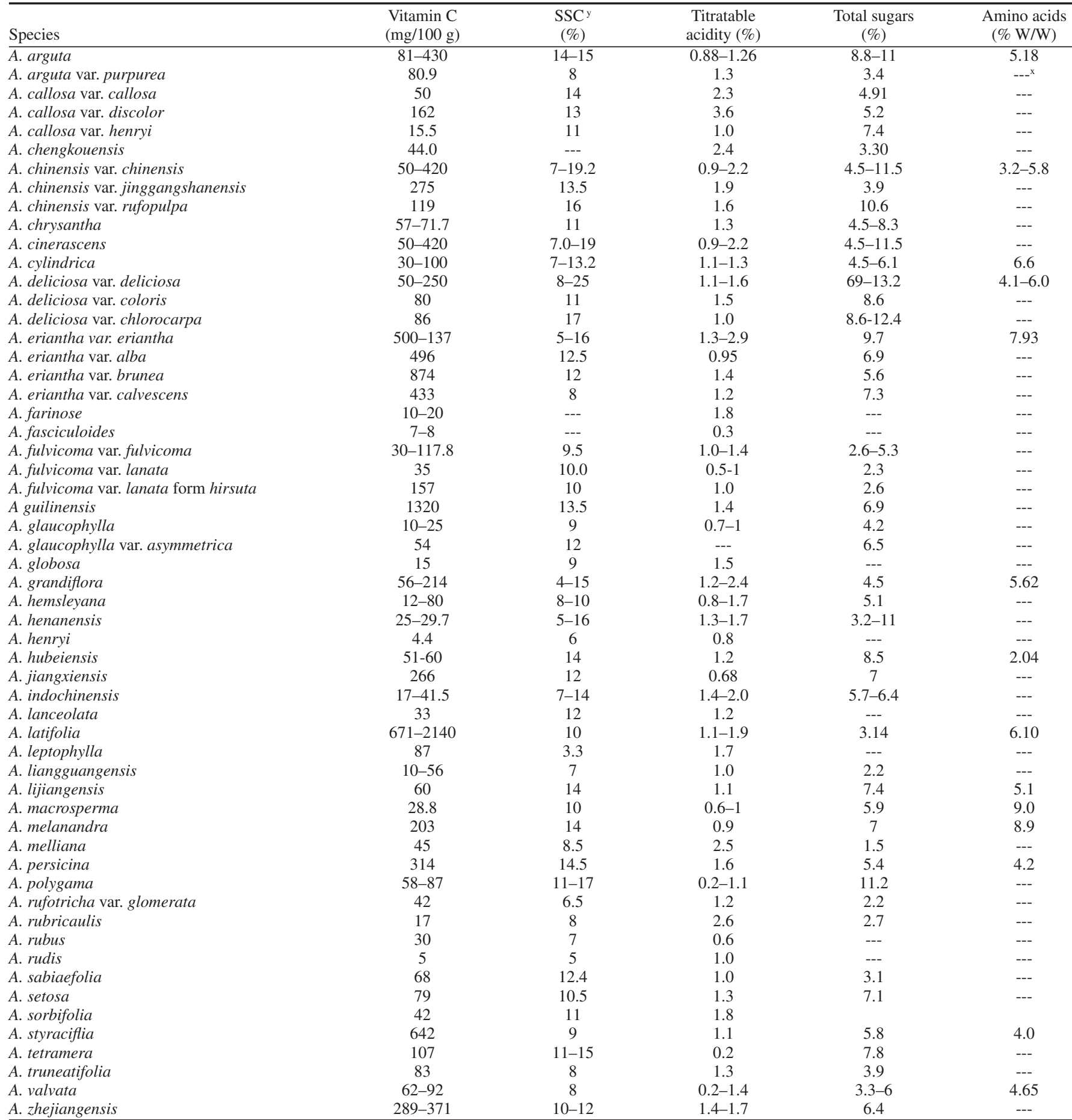

${ }^{2}$ Data source: computer database of Actinidia research center, Wuhan Institute of Botany, CAS.; Cui, Z. (eds.) 1993. Actinidia in China. Shandong Science and Technology Press.

${ }^{y}$ Soluble solids concentration.

${ }^{x}$ Data not available. 
sium from $0.2 \%$ to $0.3 \%$, and low sodium $<0.002 \%$. The medicinal or health benefit of the kiwifruit has also been shown in limited clinical studies. Preliminary evidence indicates that the fruit has laxative effect and medical benefits for enteric malfunctions (Cui, 1993). Limited studies analyzing vitamins A and B and various amino acids indicate that kiwifruit have relatively high contents of these health beneficial constituents. Table 2 lists major nutritional values important to horticulturists and breeders.

\section{Ploidy Variation}

Actinidia is one genus with tremendous interspecific and intraspecific variation in ploidy. A unique characteristic of this ploidy variation is the structured reticulate pattern including diploids, tetraploids, and hexaploids in diminishing frequency and rekindled to the geographic distribution of ploidy races (Ferguson et al., 1997; Xiong 1992; Yan et al., 1994). The basic chromosome number of 29 is widely accepted, although this could be of ancient polyploid origin (Huang et al., 1998; McNeilage and Considine, 1989). Of the 48 taxa studied so far, 40 contain diploids, 19 contain tetraploids, 5 contain hexaploids and 1 contains an octaploid (Table 3 ). The intra-taxon ploidy variation has been observed in 15 taxa. Ten taxa have diploid and tetraploid races: $A$. callosa var. discolor C.F. Liang, A. callosa var. henryi Maxim., A. chinensis var. chinensis, A. cylindrica var. reticulata C.F. Liang, A. grandiflora, A. indochinensis Merr., A. kolomikta, A. polygama, A. rubricaulis var. rubricaulis Dunn, and A. sabiifolia Dunn. Two taxa have tetraploid and hexaploid races: A. deliciosa var. chlorocarpa (C.F. Liang) C.F. Liang et A.R. Ferguson and A. valvata var. valvata Dunn. A. arguta var. arguta has the greatest intra-taxon variation including diploids, tetraploids and hexaploids. A. arguta var. purpurea (Rehd.) C.F. Liang contains tetraploids and octaploids. A. arguta contains all ploidy races, offering great potential for ploidy manipulation through breeding (Ferguson et al., 1996).

Due to the limited sampling of cytogenetic studies for ploidy analysis, the extent of both interspecific and intraspecific ploidy variation is expected to be changing when more samples are subjected to chromosome checking or even when more populations of certain taxa are studied. The intra-taxon ploidy variation has been investigated most extensively in $A$. chinensis when Xiong (1992) first reported large-fruited tetraploid plants with 116 chromosomes from southeast Hubei and north Jiangxi provinces, China. HortResearch, New Zealand, took a further step in screening $>100$ genotypes from 45 accessions of $A$. chinensis held in the HortResearch repository. They found that $60 \%$ of the genotypes were diploids and $40 \%$ were tetraploids (Yan et al., 1994). This led to the hypothesis that distribution of ploidy races is geographically oriented and that tetraploids of $A$. chinensis are primarily restricted to the mountainous areas of southeast Hubei, north Jiangxi and north Fujian, China (Ferguson et al., 1997). While it may be true that most large-fruit-sized selections of $A$. chinensis are tetraploids (Huang et al., 1997), a positive correlation between ploidy level and fruit size may exist. Although no obvious morphological difference has been established between the diploid and tetraploid A. chinensis, an experienced breeder can usually identify tetraploids from the diploids by variations in leaf thickness (Lowe, HortResearch, New Zealand, personal communication). The leaves of tetraploids are generally thicker and darker green in color than those of diploids (Huang, personal observation). Intrataxon ploidy variation poses difficulties to kiwifruit breeders who are forced to obtain ploidy information before hybridizations should be made. Before the discovery of intraspecific ploidy races, breeders were puzzled why crosses between

Table 3. Ploidy diversity in Actinidia ${ }^{2}$.

\begin{tabular}{|c|c|c|}
\hline Species & Ploidy & Chromosome no. \\
\hline A. arguta var. arguta & $2 \mathrm{x}, 4 \mathrm{x}, 6 \mathrm{x}$ & $58,116,174$ \\
\hline A. arguta var. purpurea & $4 \mathrm{x}, 8 \mathrm{x}$ & $116^{y}$ \\
\hline A. arisanensis & $2 \mathrm{x}$ & 58 \\
\hline A. callosa var. discolor & $2 \mathrm{x}, 4 \mathrm{x}$ & 58,116 \\
\hline A. callosa var. henryi & $2 \mathrm{x}, 4 \mathrm{x}$ & 58,116 \\
\hline A. callosa var. strigosa & $4 \mathrm{x}$ & 116 \\
\hline A. chinensis var. chinensis & $2 \mathrm{x}, 4 \mathrm{x}$ & 58,116 \\
\hline A. chrysantha & $4 \mathrm{x}$ & 116 \\
\hline A. cylindrica var. cylindrica & $2 \mathrm{x}$ & 58 \\
\hline A. cylindrica var. reticulata & $2 \mathrm{x}, 4 \mathrm{x}$ & 58,116 \\
\hline A. deliciosa var. deliciosa & $6 \mathrm{x}$ & 174 \\
\hline A. deliciosa var. chlorocarpa & $4 \mathrm{x}$, aneuploid?, $6 \mathrm{x}$ & $116,160 ?, 174$ \\
\hline A. eriantha var. eriantha & $2 \mathrm{x}$ & 58 \\
\hline A. eriantha f. alba & $2 \mathrm{x}$ & 58 \\
\hline A. eriantha var. brunea & $2 \mathrm{x}$ & 58 \\
\hline A. eriantha var. calvescens & $2 \mathrm{x}$ & 58 \\
\hline A. farinose & $2 \mathrm{x}$ & 58 \\
\hline A. fulvicoma var. fulvicoma & $2 \mathrm{x}$ & 58 \\
\hline A. fulvicoma var. lanata & $2 \mathrm{x}$ & 58 \\
\hline A. glaucophylla var. glaucophylla & $2 \mathrm{x}$ & 58 \\
\hline A. glaucophylla var. astymmetrica & $4 \mathrm{x}$ & 116 \\
\hline A. grandiflora & $2 \mathrm{x}, 4 \mathrm{x}$ & 58,116 \\
\hline A. guilinensis & $2 \mathrm{x}$ & 58 \\
\hline A. hemsleyana var. hemsleyana & $2 \mathrm{x}$ & 58 \\
\hline A. hubeiensis & $2 x$ & 58 \\
\hline A. hypoleuca & $2 \mathrm{x}$ & 58 \\
\hline A. indochinensis & $2 \mathrm{x}, 4 \mathrm{x}$ & 58,116 \\
\hline A. kolomikta & $2 x, 4 x$ & 58,116 \\
\hline A. lanceolata & $2 \mathrm{x}$ & 58 \\
\hline A. latifolia var. latifolia & $2 \mathrm{x}$ & 58 \\
\hline A. liangguangensis & $2 \mathrm{x}$ & 58 \\
\hline A. lijiangensis & $2 \mathrm{x}$ & 58 \\
\hline A. macrosperma var. macrosperma & $4 \mathrm{x}$ & 116 \\
\hline A. macrosperma var. mumoides & $4 \mathrm{x}$ & 116 \\
\hline A. melanandra var. melanandra & $2 \mathrm{x}, 4 \mathrm{x}$ & 58,116 \\
\hline A. melliana & $2 \mathrm{x}$ & 58 \\
\hline A. persicina & $2 \mathrm{x}$ & 58 \\
\hline A. polygama & $2 x, 4 x$ & 58,116 \\
\hline A. rubricaulis var. rubricaulis & $2 \mathrm{x}, 4 \mathrm{x}$ & 58,116 \\
\hline A. rubricaulis var. coriacea & $2 \mathrm{x}$ & 58 \\
\hline A. rufa & $2 \mathrm{x}$ & 58 \\
\hline A. rufotricha var. glomerata & $2 \mathrm{x}$ & 58 \\
\hline A. sabiifolia & $2 \mathrm{x}, 4 \mathrm{x}$ & 58,116 \\
\hline A. setosa & $2 \mathrm{x}$ & 58 \\
\hline A. styraciflia & $2 \mathrm{x}$ & 58 \\
\hline A. tetramera & $2 \mathrm{x}$ & 58 \\
\hline A. valvata var. valvata & $4 x, 6 x$ & 116,174 \\
\hline A. zhejiangensis & $2 \mathrm{x}$ & 58 \\
\hline
\end{tabular}

${ }^{2}$ Data source: data from the computer database of Actinidia research center, Wuhan Institute of Botany, CAS., both male and female plants of most species were recently checked for chromosome numbers (including the published data on species by Xiong et al., 1985; Xiong and Huang, 1988), except A. arguta 6x, A. arisanensis 2x from Blanchet et al., 1992; A. hypoleuca 2x from McNeilage and Considine, 1989; and A. arguta var. purpurea 8x from Ferguson et al., 1997. Chromosome number was determined as follows: cell wall enzyme digesting, low osmotic pressure, slides flame drying, Giemsa dying and counting by Olympus-BH.

yFlow cytometry estimated. two A. chinensis plants were less successful than when two different species, such as $A$. chinensis $\mathrm{X}$ A. eriantha, were crossed (Wang et al., 1989, 1994; Xiong, 1990). On the other hand, by precisely understanding ploidy variation involved, kiwifruit breeders have the opportunity to create new ploidy germplasm, novel breeding lines or even novel cultivars. With aid of embryo rescue technology and tissue culture methods (Mu et al., 1990, 1992), a continuous variation from diploid to octaploids and even aneuploids could possibly be created. Dodecaploid somaclones of A. deliciosa were found from leaf-derived callus tissue cultures Boase and Hopping, 1995). Obtaining ploidy information before selecting breeding parents should be now considered a routine procedure 
in kiwifruit breeding. Manipulating ploidy variants may also enhance our understanding of ploidy nature, i.e., autopolyploidy vs. allopolyploidy. There is evidence indicating that the tetraploid A. chinensis is autotetraploid and hexaploid $A$. deliciosa is allohexaploid (Huang et al., 1997). Understanding the gamete tetrasomic segregation of the tetraploid A. chinensis in crosses would also be helpful for estimating ploidy genotype frequencies, progeny seedling survival rate and creating various ploidy genotypes.

\section{Isozyme Genetic Variation}

Although only a few studies have been conducted and limited information is available, all existing results suggest that the genetic diversity of Actinidia at the isozyme level is extraordinary high (Huang et al., 1997; Messina et al., 1991; Testolin and Ferguson, 1997). After examining 22 Chinese cultivars selected from the wild and 56 plants from 28 Actinidia taxa using 10 isozyme markers, Huang et al. (1997) observed a high level of isozyme variation and heterozygosity both in the cultivars and in the taxa. For example, in 22 cultivars examined, the isozymic heterozygosity of 10 isozyme loci ranged from $18 \%$ to $100 \%$ and average heterozygosity was $65.1 \%$. A wide range of different isozymic heterozygosity was also observed in different taxa, ranging from $68 \%$ to $100 \%$. It is reasonable to assume that the high isozymic heterozygosity observed within the genus is well in accordance with ploidy variation and other diverse characteristics of the Actinidia. It is also interesting to note that a high percentage of multi-allelic heterozygosity was found in many loci. For example, in the PGI locus, tetra-allelic, tri-allelic and diallelic heterozygotes were $18 \%, 27 \%$, and $55 \%$, respectively. The high percentage of di-, tri- or tetra-allelism found in allohexaploid A. deliciosa and autotetraploid A. chinensis suggested an effective maintenance of heterozygosity through polyploidy in Actinidia (Stebbins, 1950). Furthermore, higher tri- and tetra-allelic heterozygosity was observed in selected cultivars than in wild plants. This is apparently related to projected selection process, indicating that genetic heterozygosity should be an important objective in future breeding programs, particularly when mass or recurrent selection procedures are being used (Ferguson et al., 1996). When isozyme polymorphisms were used to study the taxonomic relationships among Actinidia taxa, A. chinensis was found to be the species most closely related to A. deliciosa by sharing 34 of 40 alleles. It is believed that $A$. deliciosa was derived by polyploidization solely from $A$. chinensis without any other Actinidia species being involved (Testolin and Ferguson, 1997).

\section{Genetic Diversity at the DNA Level}

The genome size (haploid) of Actinidia species is about 375 to $750 \mathrm{Mb}$ (Weising et al., 1996). Although genetic diversity at the DNA level has not been subjected to extensive evaluation in Actinidia, evidence from available research data indicates that the genus has extremely high genetic diversity in both nuclear and cytoplasmic genomes. Weising et al. (1996) evaluated eight accessions of diploid A. chinensis using 16 microsatellite DNA markers and microsatellite heterozygosity ranged from $50 \%$ to $100 \%$. They also observed a high variability of microsatellites across different species. Huang et al. (1998) evaluated four diploid and six tetraploid $A$. chinensis using 20 microsatellites and showed heterozygosity of $50 \%$ to $85 \%$ in diploids and $90 \%$ to $100 \%$ in tetraploids. The number of alleles per locus varied from 9 to 17 , with an average of 12.4 alleles per locus in A. chinensis. The intra-locus heterozygosity revealed by microsatellites in tetraploids was found to be even higher than that by isozymes. This resulted in $>60 \%$ of tri- and tetra-allelic heterozygosity in the 20 microsatellites, further demonstrating that the polyploidy maintains rich genetic diversity in Actinidia species. The genetic diversity was recently revealed by RAPDs (randomly amplified polymorphic DNA) for 39 taxa within genus Actinidia (Huang et al., 2002). Even when there were only three to five individual plants of each taxa evaluated, an average of $77 \%$ of polymorphic loci was revealed in species level and total of $91 \%$ at the genus level. Recently, Zheng et al. (2003) conducted an extensive genetic evaluation of 26 varieties of $A$. chinensis and 19 varieties of $A$. deliciosa, respectively, using 9 SSR markers. The gene diversity in $A$. chinensis was $89 \%$ while that in A. deliciosa $91 \%$. Analysis of the distribution of genetic diversity showed that $97.83 \%$ and $2.17 \%$ genetic diversity occurred between and within species, respectively.

\section{DEVELOPMENT OF KIWIFRUIT INDUSTRY IN CHINA}

\section{Early Efforts}

In China, the early attempted efforts in introduction, evaluation and development of useful selections for vineyard cultivation were initiated by the Institute of Botany, The Chinese Academy of Sciences, in 1957. This pioneer program primarily emphasized on a survey of Actinidia germplasm in Taibai Mountain of the Qinling Mountain ranges, Shaanxi province, and Funiu Mountain, Henan province. A. deliciosa and A. chinensis were introduced of into the Beijing Botanical Garden for evaluation, selection and basic biological research. The program continued to introduce A. arguta, A. kolomikta, and A. ploygama into the botanical garden in 1960 . These plants have been maintained for evaluation of growth and reproduction biology for $>30$ years and the program made many contributions to our basic understanding of Actinidia biology. A similar effort in germplasm survey and selection of superior genotypes was also attempted by Central China Agricultural College in Wudangshan Mountain, Hubei province, in 1958. Neither of these early programs resulted in any significant contribution to current cultivar development and China kiwifruit industry, but a wealth of useful information on basic biology, natural habitat, genetic resources and taxonomy were generated.

\section{Selection from Natural Resources}

A government organized, nationwide selection program was initiated in China in 1977-78. This program had two primary goals: 1) a national germplasm survey and inventory of Actinidia resources and 2) selection of superior genotypes for cultivar development. The latter goal was to develop new cultivars superior over the most widely grown 'Hayward' that was developed in New Zealand from an early introduction from China in 1904. As a result, a national cooperative group for Actinidia research was founded in August 1978, with governmental initiative funds and almost all central governmental and provincial agricultural research organizations and major agricultural universities participated. This cooperative group was later integrated into a cooperative organization for scientific research under the Ministry of Agriculture in 1993. This is probably the largest program in history for selecting cultivars directly from the wild. The progress of the program can be outlined by three significant contributions. First, 61 species, 43 varieties, and 7 forms in the genus Actinidia native to China were classified based on survey data from 27 provinces. Second, an inventory of natural genetic diversity, natural resources, and distribution data was established. The naturally wild fruit production of A. chinensis and $A$. deliciosa was estimated to be $150,000 \mathrm{t} /$ year during $1980 \mathrm{~s}$, although a massive exploitation of using wild fruit for processed products without adequate measures of conservation strategy resulted in an equally massive damage to natural reserves since the mid-1980s. Third, >1400 superior genotypes were selected from wild populations of $A$. chinensis, A. deliciosa, and A. arguta. Most these went through the followup topworking in research stations followed by extensive evaluations, experimental trials, regional tests and replicated trials on a commercial scale. As a result, 57 cultivars and a large number of selections were developed. The outcome of this program was unique to the Chinese kiwifruit industry with a different cultivar structure from the rest of the world. Most of the newly released cultivars in China are selections from wild populations of $A$. chinensis and $A$. deliciosa. A few new cultivars of $A$. arguta were also selected from the wild but they are not yet widely accepted in commercial production and are not yet currently important to the China kiwifruit industry. The newly developed cultivars and selections show great diversity in many commercial traits, including large fruit size (average 80 to $100 \mathrm{~g}$ ), high vitamin C content (250 to $350 \mathrm{mg} / 100 \mathrm{~g}$ fresh flesh), high soluble solids content (about 26\%) and long life in cold storage (up to $120 \mathrm{~d}$ ) or at room temperature (40 d). Some cultivars and selections are very precocious and set flowers the next year after grafting; others are early productive ( $17 \mathrm{~kg} / 3$-year-old plant), cold hardy, drought tolerant, and have wider adaptability. Some cultivars or selections are particularly valuable for traits such as different maturity dates, excellent new flavors and interesting tastes, various flesh colors and special appeal for processed products. 


\section{CURRENT KIWIFRUIT INDUSTRY IN CHINA}

\section{Acreage and Production}

Over the past 2 decades there has been very extensive planting of kiwifruit in China, so that more kiwifruit are grown in China now than in any other country. Kiwifruit production in China is expanding rapidly and could soon have a significant impact on international kiwifruit industry (Huang and Ferguson, 2001). In the early phase of commercial development from 1978-91, commercial vineyards were first established in Hubei and Sichuan provinces in 1978, mainly using the A. deliciosa cultivar 'Hayward' from NewZealand. By 1990, the total area planted in China had expanded to 4,000 ha and the following year to 8,300 ha. From 1991-2002, commercial plantings increased very rapidly to the present 57,396 ha. Production likewise increased rapidly from 5,000 t in 1990 to $291,450 \mathrm{t}$ in 2001 . It is estimated that in 2002 , the total production of kiwifruit in China was about 340,420 t. China has now surpassed Italy and New Zealand in kiwifruit production and become the largest producer in the world.

In 2001-02, the total area in kiwifruit production was comprised of about $80 \%$ A. deliciosa cultivars and 20\% A. chinensis. One-third of the plantings were still very young and below cropping age in 2001. Most of the remaining area was in young vineyards, 4 to 7 years old and about $30 \%$ of the total area was in vineyards that have reached cropping maturity. The young age of most plantings accounts in part for the low average production in China, $<5 \mathrm{t} \cdot \mathrm{ha}^{-1}$. Even if few new plantings are established, total kiwifruit production in China should increase markedly for the next 3 or 4 years. Yields in mature fruiting vineyards are still low, however, averaging about $9 \mathrm{t} \cdot \mathrm{ha}^{-1}$. Such a rapid increase of Chinese kiwifruit production is largely due to the tremendous change of overall Chinese market economy in the past decade, private sector has been playing more important roles in economic driven of profitable agricultural industries. The Chinese kiwifruit industry is still young, profitable and rapidly developing industry, it is quite possible that as the vines age, as kiwifruit growers become more experienced with this new crop and as vine management improves, yields could approach the world average of about $15 \mathrm{t} \cdot \mathrm{ha}^{-1}$.

\section{Cultivars in Production}

Kiwifruit plantings in China are very diverse. The A. deliciosa cultivar 'Qinmei' is the most extensively planted but still accounts for little more than $30 \%$ of the total plantings and no other cultivar accounts for even $15 \%$ of the total area. Although China is rich in Actinidia germplasm, the imported cultivar 'Hayward' is the second most extensively planted, and is often preferred for the quality of its fruit. Four cultivars of A. deliciosa ('Qinmei' 30.5\%, 'Hayward' $13.2 \%$, 'Miliang-1' $9.7 \%$, and 'Jinkui' $4.0 \%$ ) and four of A. chinensis ('Kuimi' $5.4 \%$, 'Jinfeng' $4.7 \%$, 'Zaoxian' $4.0 \%$, and 'Hongyang' $3.8 \%$ ) together account for just over $75 \%$ of the total area in kiwifruit.

The cultivars are generally restricted to one or two provinces and none is grown extensively in many provinces. The most obvious example is 'Qinmei': although the area planted in this cultivar is six times that planted of any other single cultivar, the plantings are largely confined $(85 \%)$ to Shaanxi, the province where it was selected. 'Yate' was selected in and is almost exclusively grown in Shaanxi. Likewise, 'Hongyang' was selected in Sichuan and is mainly grown in that province. When a particular cultivar is grown in two or more provinces, these provinces are usually contiguous. Although cultivar choice may reflect climatic requirements and adaptation to a particular environment, it does seem that there is often a strong preference for local selections.

About $6 \%$ of the plantings are described as early maturing, i.e., harvested before mid-September. These would be almost entirely cultivars of A. chinensis. Another 30\%, comprising cultivars of both $A$. chinensis and A. deliciosa, are midseason and are harvested between midSeptember and early October. The remaining $64 \%$, mainly of cultivars of $A$. deliciosa, are late maturing and harvested between mid-October and mid-November. The lack of cooling or storage facilities in many areas of China means that there is a preference for cultivars which can be harvested later in the season when temperatures are lower and fruit have less field heat. Until now, underground cellars for short-term storage is still a common practice in many kiwifruit production areas where modern cold-storage facilities are not available.

\section{OPPORTUNITIES AND CHALLENGES}

\section{Opportunities}

With increasing consumer awareness of the nutritional value of kiwifruit and its potential contribution to a healthy diet, the per capita consumption of kiwifruit will hopefully increase thus enhancing the future development of China kiwifruit industry. Further exploitation of kiwifruit's nutritional and functional food values should provide new incentive for promoting kiwifruit in the fresh fruit market.

A well-established infrastructure of germplasm repositories and active research programs in evaluation of the germplasm resources are continuously supporting the sustainable development of the industry.

Defined breeding goals and streamlining new releases of novel cultivars from main breeding programs in China will increase market share and develop new niches in world fresh fruit market.

There is an abundance of natural resources for any new genes useful for future consumer demands and production needs.

New developments in the breeding technology, orchard management, harvest and handling, storage and processing, etc., will be available for future development of the industry.

\section{Challenges}

The role of Chinese production in the international kiwifruit market needs to be defined, taking into account that three of the four main producing countries are dependent on exports. Many problems within the current Chinese kiwifruit production system, such as lack of market regulation, poor quality control, and high percentage loss in handling and storage, need to be improved. The infrastructure, such as establishing domestic and exporting trade centers also need to be enhanced for Chinese kiwifruit marketing capacity.

The danger exists for overproduction because of not enough efforts in market promotion, consumer education, and exploitation of new uses.

New products are needed for enhancing the consumption and production.

Serious genetic erosion of natural resources and challenges for rigid sampling and collecting from the wild, and better management strategies of germplasm resources need to be considered.

Worldwide coordination in efforts of germplasm evaluation and developing new cultivars and high quality products is required to meet consumers' preference.

We can anticipate that Chinese kiwifruit production will increase rapidly in next a few years. Total production may exceed 500,000 $\mathrm{t}$ by 2005 or 2006 , producing more than half of the world kiwifruit. Until now Chinese kiwifruit export has been negligible in the world kiwifruit trade and essentially all kiwifruit produced in China have been consumed within China. Although many problems exist in the Chinese kiwifruit production and marketing system, China should soon be an important player in the international kiwifruit trade as storage facilities and marketing infrastructure are further improved.

\section{Literature Cited}

Boase, M. R. and M. E. Hopping. 1995. DNA dodecaploid plants detected among somaclones of Actinidia deliciosa. Plant Cell Rpt. 14: 319-323

Cui,Z. 1993. Actinidia in China. Shandong Scientific Press, Jinan, Shandong, P. R. China.

Ferguson, A. R. 1990. The genus Actinidia, p. 15-35. In: I.J. Warrington and G.C. Weston (eds.). Kiwifruit: Science and management. Ray Richards Publ., Auckland, N.Z.

Ferguson, A.R. and E.G. Bollard. 1990. Domestication of the kiwifruit, p. 165-246. In: I.J. Warrington and G.C. Weston (eds.). Kiwifruit: Science and management. Ray Richard Publ., Auckland, N.Z.

Ferguson, A.R., A.G. Seal, M.A. McNeilage, L.G. Fraser, C.F. Harvey, and R.A. Beatson. 1996. Kiwifruit, p. 371-417. In: J. Janick and J.N. Moore (eds.). Fruit breeding. vol. 2. Vine and small fruit. John Wiley \& Sons, New York.

Ferguson, A.R., I.e., W. O'Brien, and G J.Yan. 1997. Ploidy in Actinidia. Acta Hort. 444:68-72.

Ferguson, A.R. 2001. Kiwifruit: Is China a threat? Orchardist N.Z. 74:40-44.

Huang, H., F. Dane, Z.R. Wang, Z.W. Jiang, R.H. Huang, and S. Wang. 1997. Isozyme inheritance and variation in Actinidia. Heredity 78: 328-336.

Huang, H., J. Gong, S. Wang, Z. He, Z. Zhang, and J. Li. 2000. Genetic diversity in the genus Actinidia. Chinese Biodiversity 8:1-12.

Huang, H. and A.R. Ferguson. 2001. Kiwifruit in China. N.Z. J. Crop Hort. 29:1-14. 
Huang, H., Z. Li, J. Li, T.L. Kubisiak, and D.R. Layne. 2002. Phylogenetic relationships in Actinidia as revealved by RAPD analysis. J. Amer. Soc. Hort. Sci. 127:759-766.

Huang, H. 2003. Integrating both nuclear and cytoplasmic genetic information into a high genomic coverage conservation approach for Actinidia. Acta Hort. 610:87-93.

Huang, W.G., G. Cipriani, M. Morgante, and R. Testolin. 1998. Microsatellite DNA in Actinidia chinensis: Isolation, characterization, and homology in related species. Theor. Appl. Genet. 97: 1269-1278.

Liang, C. 1983. On the distribution of Actinidia. Guihaia 3:229-248.

McNeilage, M.A. and J.A. Considine. 1989. Chromosome studies in some Actinidia taxa and implications for breeding. N.Z. J. Bot. 27:71-81.

Messina, R., R.Testolin, and M. Morgante. 1991. Isozymes for cultivar identification in kiwifruit. HortScience 26:899-902.
Mu, S.K., L.G. Fraser, and C.F. Harvey. 1990. Rescue of hybrid embryos of Actinidia species. Scientia Hort. 44:97-106

Mu, X.J., D.R. Tsai, H.X. An, and W.L. Wang. 1992. Embryology and embryo rescue of interspecific hybrids in Actinidia. Acta Hort. 297:93-98

Stebbins, Jr., G.L.. 1950. Variation and evolution in plants. Columbia Univ. Press, New York.

Testolin, R. and A.R. Ferguson. 1997. Isozyme polymorphism in the genus Actinidia and the origin of the kiwifruit genome. Syst. Bot. 22: $685-700$.

Wang, S., X. Wu, R. Huang, Z. Xiong, and S. Ke. 1989. Preliminary report on fluctuation of interspecific cross of chinese gooseberry. J. Wuhan Bot. Res. 7:399-402

Wang, S., R. Huang, X. Wu, and L. Kang. 1994. Studies on Actinidia breeding by intespecific hybridization. J. Fruit Sci. 11:23-26

Weising, K., R.W.M. Fung, D.J. Keeling, R.G. Atkinson, and R.C. Gardner. 1996.Characterization of microsatellites from Actinidia chinensis. Mol. Breed. 2:117-131.

Xiong,Z., R. Huang, and X. Wu. 1985. Observations on the chromosome numbers of 4 species in Actinidia. J. Wuhan Bot. Res. 3:219-224.

Xiong, Z. and R. Huang. 1988. Chromosome numbers of 10 species and 3 varieties in Actinidia Lindl. Acta Phytotaxonomica Sinica 26:245-247.

Xiong, Z. 1990. Observation on the morphology and meiosis of interspecific hybrid triploid in Actinidia. Bul. Bot. Res. 10:99-103.

Xiong, Z. 1992. Chromosome studies on cultivated chinese gooseberry. Guihaia 12:79-82.

Yan, G.J., A.R. Ferguson, and M.A. McNeilage. 1994. Ploidy races in Actinidia chinensis. Euphytica 78:175-183.

Zheng, Y., Z. Li, and H. Huang. 2003. Molecular characterization of kiwifruit varieties using SSR markers. Acta Hort. 610:343-347. 